\title{
ECONOMIC EFFECTS OF INTENSIFYING PRODUCTION OF MAIN FIELD CROPS ${ }^{1}$
}

\author{
Mihajlo Munćan ${ }^{2}$
}

\section{Summary}

The starting hypothesis of the present study was the assumption that the intensity of production of main field crops on family farms can be raised to a higher level by rational use of mineral fertilizers as one of the fastest, simplest and economically most rational measures. The determination/resolution to increase the level of intensity of production of main crops in this way has derived from the results of the survey conducted on 75 family farms in Vojvodina, which showed that family farms, despite the performed analysis of soil fertility and received recommendations from the expert agricultural services for optimum application of mineral fertilizers, in most cases (73\%) did not respect obtained recommendations. Therefore the aim of this paper is to estimate the economic effects of the intensifying production of main field crops on family farms through rational use of mineral fertilizers. The obtained results show that the most significant economic effects of intensifying production can be achieved on farms of 10-20 ha of arable land.

Key words: intensifying, mineral fertilizers, field crops, family farms, economic effects

JEL: Q12, Q14

\section{Introduction}

High share of small family farms, low level of agricultural technology, deficiencies in the application of modern agro-technical measures in field crop production, a small percentage of irrigated land, etc., have a strong impact on the fluctuations in the production of major field crops in Serbia. The period from 2011 to 2014, is marked by significant annual variations of realized yields and total production volume. Yields of main field crops, in the said period, on average were as follows: wheat $4.10 \mathrm{t} / \mathrm{ha}$, maize $5.84 \mathrm{t} / \mathrm{ha}$, sunflower $2.52 \mathrm{t} / \mathrm{ha}$, soybean 2.58 $\mathrm{t} / \mathrm{ha}$ and sugar beet $47.29 \mathrm{t} / \mathrm{ha}$, and in average about $40 \%$ lower compared to yields achieved

1 Paper represents a part of the research on the project „Serbian Rural Labour Market and Rural Economics - Revenue Diversification and Poverty Mitigation", No. ON179028, financially supported by the Ministry of Education, Science and Technological Development of the Republic of Serbia, period 2011-2014.

2 Mihajlo Munćan Ph.D., Assistant Professor, University of Belgrade, Faculty of Agriculture, Nemanjina Street no. 6, 11080 Zemun, Serbia, Phone: +381 114413416 , E-mail: mmuncan@agrif.bg.ac.rs. 
in the EU during the same period. The realized yield of main field crops, is under major impact of the adequate application of agro-technical measures (fertilization, irrigation, new varieties and hybrids, the use of plant protection products, modern means of mechanization, etc.). All of these agro-technical practices have an equal impact on yield. The application of mineral fertilizers is of special importance as evidenced by the results of numerous studies (Glamočlija, 1990; Jovanović, Bošnjak, 1997; Malešević et al., 2005; Jaćimović et al., 2006; Ljubomirović et al., 2006; Andrea et al., 2008; Đukuć et al., 2009; Maksimović et al., 2010) and assessments by FAO which show that the use of fertilizers contributes with $50 \%$ to the increase of yield (Kresović, 2010). A series of performed experiments, in particular the results achieved in practice, have shown and confirmed that the increase in yield per unit area can be achieved in the fastest and most efficient way through the rational use of mineral fertilizers (Munćan, 2016). From the above it can be concluded that the mineral fertilizers represent a powerful tool in increasing yields with high impact on the level of intensity of production. At the same time, one cannot ignore the fact that the cost of production of field crops, the cost of mineral fertilizers, is very important issue and therefore should be used rationally. According to the survey results, these costs on family farms in Vojvodina, in the period from year 2005 to 2009 , participated in the total variable cost on average with $37.2 \%$ in the production of wheat, $39.7 \%$ in the production of commercial maize, $33.6 \%$ in the production of sunflower, $30.5 \%$ in the production of soy and $33.9 \%$ in the production of sugar beet (Munćan et al. 2010).

The largest part of the agricultural production of the Republic of Serbia is realized on the territory of AP Vojvodina. This area represents in average about 52\% of the total area under field crops and over 92\% of the area under industrial plants (Bošnjak, Rodić, 2010). In addition, family farms are the most important carriers of organized agricultural production in AP Vojvodina (Božić, Munćan, 2015). According to the Agricultural Census conducted in year 2012, the number of these farms in the province stood at 146,269 which makes $23.3 \%$ of the total number of farms in the Republic of Serbia. It is questionable, how reasonable are expectations that family farms alone can find solutions to the economically optimum yield, and thus economically optimal use of mineral fertilizers for said yield. In view of the present state, it can be stated that our family farms are not capable or trained for this. In most developed countries this is done for them by experts of agricultural extension services. This is confirmed by the differences in yields, between the yield realized in Serbia and yields in developed EU member states, which appear in almost the same relation as in the use of mineral fertilizers, which means that there is almost a linear relationship between yield and increased use of fertilizers (Munćan, 2016.). Hence, the Law on Agricultural Land of 2006 (Official Gazette of RS 62/06) stipulates that "for the protection and preservation of chemical and biological properties of agricultural land, from first to fifth cadastre class, and in order to ensure the correct use of mineral and organic fertilizers and pesticides, the owner, i.e. the user of arable land is obligated to control the fertility of arable land and keep records of the quantity of applied mineral fertilizers and pesticides. The control of fertility of arable land and the amount of applied mineral fertilizers and pesticides is carried out when necessary, but at least every five years". Since the adoption of the Law, the land plot/parcel owners and 
users, as well as experts of regional agricultural extension services have sampled the soil of family farms. In less than three years 70,189 samples have been collected and analysed, and recommendations given for rational fertilization using mineral fertilizers (Sekulić et al., 2009.). The starting hypothesis of the present study was the assumption that the intensity of production of main field crops on family farms, can be raised to a higher level by rational use of mineral fertilizers as one of the fastest, simplest and economically most rational measures (does not require additional investments). The determination/resolution to increase the level of intensity of production of main crops in this way has derived from the results of the survey conducted on family farms in Vojvodina. The survey showed that family farms, despite the performed analysis of soil fertility and received recommendations from the expert agricultural services for optimum application of mineral fertilizers, in most cases $(73 \%)$ do not respect obtained recommendations, but apply mineral fertilizers in accordance with their habits and financial capabilities.

\section{The subject and objective of the study}

From the above presented facts, the economic effects of intensifying production of main field crops (wheat, maize, sunflower, soybean and sugar beet) on family farms in the region of Vojvodina are the subject of research in this study. Considering that according to the Agricultural Census data from 2012, about 63\% of family farms in Vojvodina cultivate less than 5 ha of land and in total use about $11 \%$ of arable land, and since small farms are likely to continue to produce mainly for their own consumption and will be even less integrated into the market after joining the EU (Kostov, Lingard, 2002), the present study has included only the larger family farms, the size of 10 to 100 ha of arable land, registered in the Register of agricultural holdings and focused solely on agricultural production ${ }^{3}$. Preference given to family farms of this size as the focus of attention of this study resulted from the fact that:

- according to the results of the Agricultural Census in 2012, said family farms use about 60\% of arable land in Vojvodina and

- the basic condition for eligibility for any state subsidy in agriculture, in addition to registration in the Register of agricultural holdings, is that farm size does not exceed 100 ha of arable land ${ }^{4}$.

Given the importance of the research subject, the aim of this study is to estimate the economic effects of intensifying production of main field crops on family farms through rational use of mineral fertilizers.

\section{The data source and methods}

The data collected in a survey which included 75 family farms engaged exclusively

3 The study covered only family farms of the size that allows their survival in the future and retaining of their commercial character.

4 Law on Incentives in Agriculture and Rural Development "Official Gazette of the Republic of Serbia" no. 10/13.

EP 2017 (64) 2 (571-586) 
in agricultural production from the region of Vojvodina ${ }^{5}$ was used as the main source of information. The main reason why the region of Vojvodina was placed in the focus of this study has come from the fact that the results of the Agricultural Census of 2012 showed that this region, compared to the total Republic of Serbia, and the remaining three regions, is characterized by the following: significantly larger average size of farms; the lowest share of small family farms up to 5 ha in total utilized agricultural land; the highest share of farms with over 50 ha; the highest average economic size of farms, etc. In order to select a representative sample that would allow generalization of the results obtained in this research, it was necessary to perceive the characteristics of family farms and the production of main field crops in the region of Vojvodina in certain areas ${ }^{6}$. The South Banat area has been identified as the most important area for production of field crops on family farms in the region of Vojvodina based on the following indicators: share of this area in the total used agricultural and arable land; the total number of family farms; share of major field crops in sowing structure of arable land owned by family farms; number and structure of family farms of 10 - 100 ha and share of family farms of 10 - 100 ha in total volume of production of main field crops in the region of Vojvodina. The survey which included family farms engaged exclusively in the agricultural production in the South Banat area, conducted in the period from 2011 to 2014, formed the material for this study. The survey covered family farms of 10 - 100 ha of arable land and five main field crops (maize, wheat, sunflower, soybean and sugar beet), which are considered main crops due to the fact that the survey conducted in the period 2011 - 2014 showed that on average around $86 \%$ of arable land of family farms in this area was used annual in production of said crops. All surveyed family farms from the territory of South Banat area, were classified by the size of arable land used into three groups (10-20 ha, 20-50 ha, 50-100 ha).

In addition to the indicators relevant to the functioning of the family farms, the data for 390 cadastral plots that have been tested for parameters of soil fertility were also collected during the survey, and recommendations given on quantities and types of mineral fertilizers for the rational fertilization of said soil, in order to achieve the projected yields.

The four year average prices (years 2011- 2014) realized on surveyed family farms were used in the calculation of the value indicators. Average prices were used in order to avoid the impacts of extreme natural conditions on achieved production results in some years (for instance, very low yields due to drought in 2012) and the annual fluctuations in the prices of inputs and outputs that occur as a result of disturbed market relations.

5 Region is a statistical functional territorial unit, consisting of one or more areas, established for the purpose of planning and implementing regional development policy, in accordance with the nomenclature of statistical territorial units at level 2, not an administrative territorial unit and has no legal personality; Regional Development Act "Official Gazette of RS", No. 51/09

6 Area is a statistical functional territorial unit, established for the purpose of planning and implementing regional development policy, in accordance with the nomenclature of statistical territorial units at level 3, not an administrative territorial unit and has no legal personality; Regional Development Act “Official Gazette of RS” No. 51/09. 
To assess the economic effects of intensifying the production of main field crops, the method of calculation and method of comparison of obtained results were applied.

\section{Research results}

When considering the many problems related to the planning, organization and use of mineral fertilizers in the production of main field crops on family farms, it is necessary to know the distribution of areas that represent certain types, subtypes and varieties of soil. By measuring the surface of certain types, subtypes and varieties of soil using plannimetre on the pedological map of Vojvodina, in the ratio of 1: 50000, data were obtained on their presence in certain parts of Vojvodina (Živković et al., 1972). According to the results of these measurements, in the area of South Banat, two types of soil are dominant: carbonate chernozem on loess plateau and marsh smonitsa.

By analysing the spreading of carbonate chernozem on loess plateau in some land areals of South Banat area, it usually begins with contour lines $100 \mathrm{~m}$ above sea level. This type of soil covers several parts of Deliblat loess plateau (119-127 m), including, among others, the largest parts of the cadastral municipalities: Banatski Karlovac, Nikolinci, Uljma, Izbište, Zagajica, Parta and Orešac. Precisely on the territory of mentioned cadastral municipalities 45 family farms were surveyed, and, among other things, data collected on the results of soil fertility parameters for 190 cadastral parcels of total area of 593.63 ha. Average values of the surface and the content of certain nutrients are given in Table 1.

Table 1. Surface and chemical properties of carbonate chernozem on loess plateau

\begin{tabular}{|c|c|c|c|c|c|}
\hline \multirow[b]{2}{*}{ Indicator } & \multirow{2}{*}{$\begin{array}{c}\text { Surface } \\
\text { ha }\end{array}$} & \multirow{2}{*}{$\begin{array}{c}\text { Humus } \\
\%\end{array}$} & \multicolumn{3}{|c|}{ Soil nutrients } \\
\hline & & & $\begin{array}{c}\text { Total N } \\
\% \\
\end{array}$ & $\begin{array}{c}\mathrm{P}_{2} \mathrm{O}_{5} \\
\mathrm{mg} / 100 \mathrm{~g}\end{array}$ & $\begin{array}{c}\mathrm{K}_{2} \mathrm{O} \\
\mathrm{mg} / \mathbf{1 0 0} \mathrm{g}\end{array}$ \\
\hline $\begin{array}{l}\text { A v e r a g e } \\
\text { value }\end{array}$ & 3.12 & 3.27 & 0.195 & 43.77 & 29.3 \\
\hline Minimum & 0.47 & 2.19 & 0.131 & 5.49 & 11.5 \\
\hline Maximum & 23.10 & 4.35 & 0.289 & 238.82 & 77.4 \\
\hline $\begin{array}{l}\text { Variation } \\
\text { interval }\end{array}$ & 22.63 & 2.589 & 0.158 & 233.33 & 65.92 \\
\hline $\begin{array}{l}\mathrm{S} \text { t a n d a r d } \\
\text { deviation }\end{array}$ & 3.51 & 0.543 & 0.030 & 33.344 & 13.608 \\
\hline $\begin{array}{l}\text { Variation } \\
\text { coefficient }\end{array}$ & 112.34 & 16.613 & 15.393 & 76.185 & 46.528 \\
\hline
\end{tabular}

Source: Calculation of the authors based on the results of the Survey

Based on obtained results of tests of soil fertility recommendations were given for rational fertilization with mineral fertilizers in order to achieve the projected yield (Table 2). 
Table 2. Recommendations for rational fertilization of carbonate chernozem on loess plateau with mineral fertilizers

\begin{tabular}{|l|c|c|c|c|c|c|c|c|c|c|c|c|}
\hline \multirow{2}{*}{ Indicator } & \multicolumn{3}{|c|}{ Wheat (6.3 t) } & \multicolumn{3}{c|}{ Maize (8.6 t) } & \multicolumn{2}{c|}{ Sunflower (3.3 t) } & \multicolumn{3}{c|}{ Sugar beet (55 t) } \\
\cline { 2 - 15 } & $\mathbf{N}$ & $\mathbf{P}_{2} \mathbf{O}_{5}$ & $\mathbf{K}, \mathbf{O}$ & $\mathbf{N}$ & $\mathbf{P}_{2} \mathbf{O}_{5}$ & $\mathbf{K} \mathbf{O}_{2} \mathbf{O}$ & $\mathbf{N}$ & $\mathbf{P}_{2} \mathbf{O}_{5}$ & $\mathbf{K}_{2} \mathbf{O}$ & $\mathbf{N}$ & $\mathbf{P}_{2} \mathbf{O}_{5}$ & $\mathbf{K}_{2} \mathbf{O}$ \\
\hline Average value & 127.58 & 32.16 & 29.55 & 138.18 & 44.78 & 43.58 & 96.61 & 28.05 & 35.11 & 145.33 & 44.67 & 112.67 \\
\hline Minimum & 90 & 0 & 0 & 96.3 & 0 & 0 & 67.5 & 0 & 0 & 135 & 23 & 99 \\
\hline Maximum & 167.2 & 77 & 48.4 & 213.4 & 110 & 77 & 133.1 & 63.8 & 59.4 & 152 & 64 & 136 \\
\hline Variation interval & 77.2 & 77 & 48.4 & 117.1 & 110 & 77 & 65.6 & 63.8 & 59.4 & 17.00 & 41.00 & 37 \\
\hline Standard deviation & 15.52 & 17.62 & 10.21 & 20.48 & 25.12 & 16.15 & 12.97 & 15.42 & 12.41 & 7.13 & 19.47 & 11.46 \\
\hline Variation coefficient & 12.17 & 54.80 & 34.55 & 14.82 & 56.08 & 37.06 & 13.43 & 54.94 & 35.34 & 4.91 & 43.6 & 10.17 \\
\hline
\end{tabular}

Source: Calculation of the authors based on the results of the Survey

In the area of South Banat, marsh smonitsa type of soil occupies spacious land complexes in the area of Vršac Rit and the most parts of cadastral municipalities of Konak, Stari Lec, Miletićevo, Banatski Sokolac, Veliki Gaj and Velika Greda. A survey of 30 family farms was conducted on the territory of mentioned cadastral municipalities and data on the results of the analysed soil fertility parameters for 200 cadastral parcels collected, total area of 386.09 hectares. Average values for the surface and the contents of certain nutrients are presented in Table 3.

Table 3. Surface and chemical properties of marsh smonitsa

\begin{tabular}{|l|c|c|c|c|c|}
\hline \multirow{2}{*}{ Indicator } & \multirow{2}{*}{$\begin{array}{c}\text { Surface } \\
\text { ha }\end{array}$} & \multirow{2}{*}{$\begin{array}{c}\text { Humus } \\
\mathbf{\%}\end{array}$} & $\begin{array}{c}\text { Total } \mathbf{~} \\
\mathbf{\%}\end{array}$ & $\begin{array}{c}\mathbf{P}_{\mathbf{2}} \mathbf{O}_{\mathbf{5}} \\
\mathbf{m g} / \mathbf{1 0 0} \mathbf{g}\end{array}$ & $\begin{array}{c}\mathbf{K}_{\mathbf{2}} \mathbf{O} \\
\mathbf{~ m g} / \mathbf{1 0 0} \mathbf{g}\end{array}$ \\
\cline { 4 - 6 } $\begin{array}{l}\text { A v e r a g e } \\
\text { value }\end{array}$ & 1.9304 & 2.88 & 0.183 & 23.98 & 25.7640 \\
\hline Minimum & 0.0698 & 1.88 & 0.113 & 1.04 & 10.58 \\
\hline Maximum & 7.1094 & 4.83 & 1.116 & 164.80 & 90.00 \\
\hline $\begin{array}{l}\text { Varia t i o n } \\
\text { interval }\end{array}$ & 7.0396 & 2.95 & 1.003 & 163.76 & 79.42 \\
\hline $\begin{array}{l}\text { S t a n d a r d } \\
\text { deviation }\end{array}$ & 1.4182 & 0.6129 & 0.0993 & 32.6308 & 12.1582 \\
\hline $\begin{array}{l}\text { Variation } \\
\text { coefficient }\end{array}$ & 73.4653 & 21.3071 & 54.2527 & 136.0433 & 47.1907 \\
\hline
\end{tabular}

Source: Calculation of the authors based on the results of the Survey

Based on obtained results the recommendations were given for rational fertilization using the mineral fertilizers in order to achieve the projected yield (Table 4).

Table 4. Recommendations for rational fertilization of marsh smonitsa with mineral fertilizers

\begin{tabular}{|l|c|c|c|c|c|c|c|c|c|c|c|c|}
\hline \multirow{2}{*}{ Indicator } & \multicolumn{3}{|c|}{ Wheat (5.8 t) } & \multicolumn{3}{c|}{ Maize (7.5 t) } & \multicolumn{3}{c|}{ Sunflower (3.0 t) } & \multicolumn{3}{c|}{ Soybean (3,3 t) } \\
\cline { 2 - 13 } & $\mathbf{N}$ & $\mathbf{P}_{2} \mathbf{O}_{5}$ & $\mathbf{K}_{2} \mathbf{O}$ & $\mathbf{N}$ & $\mathbf{P}_{2} \mathbf{O}_{5}$ & $\mathbf{K}, \mathbf{O}$ & $\mathbf{N}$ & $\mathbf{P}_{2} \mathbf{O}_{5}$ & $\mathbf{K}_{2} \mathbf{O}$ & $\mathbf{N}$ & $\mathbf{P}_{2} \mathbf{O}_{5}$ & $\mathbf{K}_{2} \mathbf{O}$ \\
\hline Average value & 131.71 & 38.33 & 33.49 & 129.55 & 59.61 & 39.87 & 103.84 & 47.98 & 38.86 & 49.56 & 38.49 & 35.48 \\
\hline
\end{tabular}




\begin{tabular}{|l|c|c|c|c|c|c|c|c|c|c|c|c|}
\hline \multirow{2}{*}{ Indicator } & \multicolumn{3}{|c|}{ Wheat (5.8 t) } & \multicolumn{3}{c|}{ Maize (7.5 t) } & \multicolumn{3}{c|}{ Sunflower (3.0 t) } & \multicolumn{3}{c|}{ Soybean $\mathbf{( 3 , 3} \mathbf{t})$} \\
\cline { 2 - 15 } & $\mathbf{N}$ & $\mathbf{P}_{2} \mathbf{O}_{5}$ & $\mathbf{K}, \mathbf{O}$ & $\mathbf{N}$ & $\mathbf{P}_{2} \mathbf{O}_{5}$ & $\mathbf{K}, \mathbf{O}$ & $\mathbf{N}$ & $\mathbf{P}_{2} \mathbf{O}_{5}$ & $\mathbf{K}_{2} \mathbf{O}$ & $\mathbf{N}$ & $\mathbf{P}_{2} \mathbf{O}_{5}$ & $\mathbf{K}, \mathbf{O}$ \\
\hline Minimum & 51.00 & 0.00 & 1.00 & 0.00 & 0.00 & 0.00 & 49.00 & 0.00 & 1.00 & 22.00 & 3.00 & 12.00 \\
\hline Maximum & 149.94 & 74.46 & 44.88 & 149.94 & 89.76 & 56.10 & 122.40 & 81.60 & 52.02 & 45.90 & 55.08 & 43.86 \\
\hline Variation interval & 98.94 & 74.46 & 43.88 & 149.94 & 89.76 & 56.10 & 73.40 & 81.60 & 51.02 & 23.90 & 52.08 & 31.86 \\
\hline Standard deviation & 15.20 & 20.74 & 7.46 & 17.67 & 25.95 & 9.53 & 12.95 & 19.16 & 9.30 & 4.97 & 12.33 & 8.23 \\
\hline Variation coefficient & 11.79 & 41.88 & 24.35 & 14.07 & 43.54 & 23.91 & 12.47 & 39.93 & 23.93 & 13.67 & 36.83 & 25.33 \\
\hline
\end{tabular}

Source: Calculation of the authors based on the results of the Survey

Based on the presented results, it is apparent that the type of soil is an important factor influencing considerably the quantity of mineral nutrients necessary to achieve appropriate yields. The analysis of certain nutrients showed that nitrogen had a dominant role and impact on the yield in all the monitored field crops. The analysis showed that nitrogen had a dominant influence on the yield of wheat, maize and sunflower on both soil types (chernozem and marsh smonitsa). Hence, for the purpose of the classification of family farms in terms of the achieved production results, in addition to the size of the farm, the most common type of soil was used as an additional criterion, based on which all surveyed family farms were classified in two variants:

- Variant I - family farms where the prevailing soil type was chernozem carbonate on loess plateau and

- Variant II - family farms where the prevailing soil type was marsh smonitsa.

\section{The effects of intensifying field crop production}

In order to evaluate the effect of intensifying production of main field crops through application of the recommended amount of mineral fertilizers, a comparative overview of the yield, the cost of fertilizers and production value before and after the intensification of the farms and variants is presented (Table 5).

Table 5. The effect of intensifying production of main field crops on different size family farms by using the recommended amount of mineral fertilizers (variant I)

\begin{tabular}{|c|c|c|c|c|c|c|c|c|c|}
\hline \multirow[b]{3}{*}{ Indicators } & \multicolumn{9}{|c|}{ Farm size (ha) } \\
\hline & \multicolumn{3}{|c|}{14.7} & \multicolumn{3}{|c|}{36.9} & \multicolumn{3}{|c|}{78.29} \\
\hline & 总 & I & 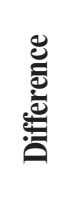 & • & 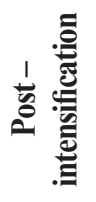 & 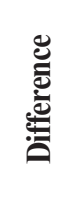 & & 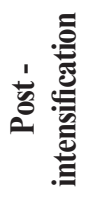 & 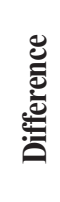 \\
\hline \multicolumn{10}{|l|}{ Yield (t/ha) } \\
\hline Wheat & 4.62 & 6.3 & 1.68 & 5.04 & 6.3 & 0.90 & 5.52 & 6.3 & 0.78 \\
\hline Maize & 7.42 & 8.6 & 1.18 & 7.76 & 8.6 & 0.84 & 8.03 & 8.6 & 0.57 \\
\hline Sunflower & 2.48 & 3.3 & 0.82 & 2.73 & 3.3 & 0.57 & 2.86 & 3.3 & 0.44 \\
\hline Sugar beet & - & - & - & 43.26 & 55 & 11.74 & 46.53 & 55 & 8.47 \\
\hline
\end{tabular}




\begin{tabular}{|c|c|c|c|c|c|c|c|c|c|}
\hline \multirow[b]{3}{*}{ Indicators } & \multicolumn{9}{|c|}{ Farm size (ha) } \\
\hline & \multicolumn{3}{|c|}{14.7} & \multicolumn{3}{|c|}{36.9} & \multicolumn{3}{|c|}{78.29} \\
\hline & 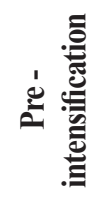 & I & 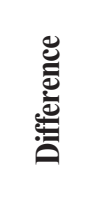 & ص. & I & 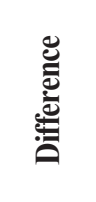 & 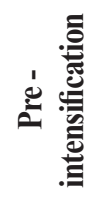 & 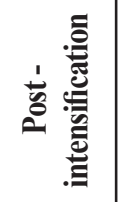 & 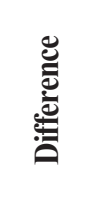 \\
\hline \multicolumn{10}{|c|}{ Cost of mineral fertilizers (RSD/ha) } \\
\hline Wheat & 16,096 & 19,392 & 3,296 & 16,976 & 19,392 & 2,416 & 17,325 & 19,392 & 2,067 \\
\hline Maize & 17,064 & 23,128 & 6,064 & 18,972 & 23,128 & 4,155 & 20,047 & 23,128 & 3,081 \\
\hline Sunflower & 12,248 & 16,464 & 4,216 & 13,605 & 16,464 & 2,859 & 14,237 & 16,464 & 2,227 \\
\hline Sugar beet & - & - & - & 29,450 & 37,500 & 8,050 & 31,230 & 37,500 & 6,270 \\
\hline \multicolumn{10}{|c|}{ Value of production (RSD/ha) } \\
\hline Wheat & 83,160 & 113,400 & 30,240 & 90,720 & 113,400 & 22,680 & 99,360 & 113,400 & 14,040 \\
\hline Maize & 115,752 & 134,160 & 18,408 & 121,056 & 134,160 & 13,104 & 125,268 & 134,160 & 8,892 \\
\hline Sunflower & 86,800 & 115,500 & 28,700 & 95,550 & 115,500 & 19,950 & 100,100 & 115,500 & 15,400 \\
\hline Sugar beet & - & - & - & 166,551 & 211,750 & 45,199 & 179,141 & 211,750 & 32,609 \\
\hline
\end{tabular}

Source: Calculation of the authors based on the results of the Survey

Analysis of yield before and after implementation of the recommended amount of mineral fertilizers, showed that the most significant effects of the intensification were realized on the smallest family farms. Namely, the obtained results of the analysis showed that these farms had the lowest level of intensity of production, i.e. that the utilization of arable land, as one of the most important natural resources for agricultural production, was not rational (Munćan et al., 2014). In contrast, the largest family farms are characterized by more rational use of arable land, considering much higher yields that are achieved, and also confirmed by the significantly lower effects realized by the intensifying of production using the recommended amounts of mineral fertilizers.

By respecting the received recommendations for rational fertilization with mineral fertilizers, the smallest family farms would increase the cost of this input in the production of wheat by $20.2 \%$, maize by $35.5 \%$ and sunflower by $34.4 \%$. As a result of increased investment in mineral fertilizers, also the average yield and production value increase, namely: wheat by $36.6 \%$, maize by $15.9 \%$ and sunflower by $33.1 \%$. On the other hand, the largest family farms, by respecting the received recommendations for rational fertilization with mineral fertilizers would increase the cost of this input in the production of wheat by $11.9 \%$, maize by $15.4 \%$, sunflower by $15.6 \%$ and sugar beet by $20.1 \%$, resulting in increased yield and value of wheat production by $14.1 \%$, maize by $7.1 \%$, sunflower by $15.4 \%$ and sugar beet by $18.2 \%$.

The value of the effect of intensifying production, calculated as the difference between the increased value of production and the increased costs of mineral fertilizers is given in Table 6 . 
Table 6. The net effect of intensifying production of main field crops through the application of the recommended quantities of mineral fertilizers on different size family farms (variant I)

\begin{tabular}{|c|c|c|c|}
\hline Crops & $\begin{array}{l}\text { Increased cost of } \\
\text { mineral fertilizers } \\
\text { (RSD/ha) }\end{array}$ & $\begin{array}{l}\text { Increased production } \\
\text { value }(\mathrm{RSD} / \mathrm{ha})\end{array}$ & $\begin{array}{c}\text { Difference (RSD/ } \\
\text { ha) }\end{array}$ \\
\hline \multicolumn{4}{|c|}{ Farm size (14.7 ha) } \\
\hline Wheat & 3,296 & 30,240 & 26,944 \\
\hline Maize & 6,064 & 18,408 & 12,344 \\
\hline Sunflower & 4,216 & 28,700 & 24,484 \\
\hline \multicolumn{4}{|c|}{ Farm size (36.9 ha) } \\
\hline Wheat & 2,416 & 22,680 & 20,264 \\
\hline Maize & 4,155 & 13,104 & 8,949 \\
\hline Sunflower & 2,859 & 19,950 & 17,091 \\
\hline Sugar beet & 8,050 & 45,199 & 37,149 \\
\hline \multicolumn{4}{|c|}{ Farm size (78.29 ha) } \\
\hline Wheat & 2,067 & 14,040 & 11,973 \\
\hline Maize & 3,081 & 8,892 & 5,811 \\
\hline Sunflower & 2,227 & 15,400 & 13,173 \\
\hline Sugar beet & 6,270 & 32,609 & 26,339 \\
\hline
\end{tabular}

Source: Calculation of the authors based on the results of the Survey

The greatest effect of increased costs of use of mineral fertilizers, as one of the measures to increase the intensity of production, was expressed also on the smallest farms and ranged from a maximum of $30,240 \mathrm{RSD} /$ ha in wheat production to a minimum 18,408 $\mathrm{RSD} /$ ha in maize production. The obtained results confirm once more the previous statement that the smallest farms apply the lowest level of intensity of production of field crops. In case of the largest family farms, due to significantly higher level of applied production intensity, the effect was slightly smaller and ranged from 5,811 $\mathrm{RSD} /$ ha in maize production to $26,339 \mathrm{RSD} /$ ha in sugar beet production.

Similar tendencies can be stated in case of family farms of the variant II. By analysing yields before and after implementation of the recommended amount of mineral fertilizers, one can observe that the most significant effects of intensifying were realized by the smallest family farms, confirming that these farms had significant opportunities to increase the level of intensity, particularly in the production of maize (Table 7). 
Table 7. The effect of intensifying production of main field crops on different size family farms by using the recommended amount of mineral fertilizers (variant II)

\begin{tabular}{|c|c|c|c|c|c|c|c|c|c|}
\hline \multirow[b]{3}{*}{ Indicators } & \multicolumn{9}{|c|}{ Farm size (ha) } \\
\hline & \multicolumn{3}{|c|}{14.7} & \multicolumn{3}{|c|}{36.9} & \multicolumn{3}{|c|}{78.29} \\
\hline & : & 点 & 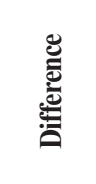 & 总 & 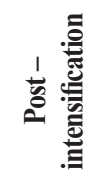 & 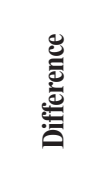 & 总 & 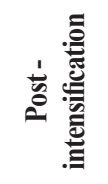 & 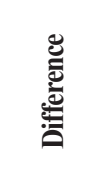 \\
\hline \multicolumn{10}{|l|}{ Yield (t/ha) } \\
\hline Wheat & 4.76 & 5.8 & 1.04 & 5.13 & 5.8 & 0.67 & 5.34 & 5.8 & 0.46 \\
\hline Maize & 5.96 & 7.5 & 1.54 & 6.21 & 7.5 & 1.29 & 6.48 & 7.5 & 1.02 \\
\hline Sunflower & 2.38 & 3 & 0.62 & 2.42 & 3 & 0.58 & 2.61 & 3 & 0.39 \\
\hline Soybean & 2.58 & 3.3 & 0.72 & 2.83 & 3.3 & 0.47 & 3.18 & 3.3 & 0.12 \\
\hline \multicolumn{10}{|c|}{ Cost of mineral fertilizers (RSD/ha) } \\
\hline Wheat & 15,270 & 20,140 & 4,870 & 16,870 & 20,140 & 3,270 & 17,570 & 20,140 & 2,570 \\
\hline Maize & 17,320 & 23,100 & 5,780 & 18,280 & 23,100 & 4,820 & 19,567 & 23,100 & 3,533 \\
\hline Sunflower & 14,890 & 20,720 & 5,830 & 15,670 & 20,720 & 5,050 & 17,020 & 20,720 & 3,700 \\
\hline Soybean & 8,220 & 11,440 & 3,220 & 8,920 & 11,440 & 2,520 & 9,180 & 11,440 & 2,260 \\
\hline \multicolumn{10}{|c|}{ Value of production (RSD/ha) } \\
\hline Wheat & 85,680 & 104,400 & 18,720 & 92,340 & 104,400 & 12,060 & 96,120 & 104,400 & 8,280 \\
\hline Maize & 92,976 & 117,000 & 24,024 & 96,876 & 117,000 & 20,124 & 101,088 & 117,000 & 15,912 \\
\hline Sunflower & 83,300 & 105,000 & 21,700 & 84,700 & 105,000 & 20,300 & 91,350 & 105,000 & 13,650 \\
\hline Soybean & 105,780 & 135,300 & 29,520 & 116,030 & 135,300 & 19,270 & 130,380 & 135,300 & 4,920 \\
\hline
\end{tabular}

Source: Calculation of the authors based on the results of the Survey

By respecting the received recommendations for rational fertilization using the mineral fertilizers, the smallest family farms of variant II would increase the cost of inputs in the production of wheat by $31.8 \%$, maize by $33.3 \%$, sunflower by $39.1 \%$ and soybean by $39.2 \%$. As a result of increased investment in mineral fertilizers, the average yield and value of wheat production is increased by $22 \%$, maize by $26 \%$, sunflower by $26 \%$ and soybean by $28 \%$. In contrast, in case of the largest family farms, the costs of mineral fertilizers would increase in production of wheat by $14.6 \%$, maize by $18 \%$, sunflower by $21.7 \%$ and soybean by $24.6 \%$, which would result in increased yield and value of wheat production by $8.6 \%$, maize by $15.7 \%$, sunflower by $14.9 \%$ and soybean by $3.8 \%$.

The net effect value of applying these measures to intensify, as the difference between the value of increased production and the increased costs of mineral fertilizers for family farms of variant II, is given in Table 8. 
Table 8. The net effect of intensifying production of main field crops through the application of the recommended quantities of mineral fertilizers on different size family farms (variant II)

\begin{tabular}{|l|c|c|c|}
\hline Crops & $\begin{array}{c}\text { Increased cost of } \\
\text { mineral fertilizers } \\
\text { (RSD/ha) }\end{array}$ & $\begin{array}{c}\text { Increased production } \\
\text { value (RSD/ha) }\end{array}$ & Difference (RSD/ha) \\
\hline Farm size (14.7 ha) & \multicolumn{5}{|l|}{} \\
\hline Wheat & 4,870 & 18,720 & 13,850 \\
\hline Maize & 5,780 & 24,024 & 18,244 \\
\hline Sunflower & 5,830 & 21,700 & 15,870 \\
\hline Soybean & 3,220 & 29,520 & 26,300 \\
\hline Farm size (36.9 ha) & 3,270 & 12,060 & 8,790 \\
\hline Wheat & 4,820 & 20,124 & 15,304 \\
\hline Maize & 5,050 & 20,300 & 15,250 \\
\hline Sunflower & 2,520 & 19,270 & 16,750 \\
\hline Soybean & 2,570 & 8,280 & 5,710 \\
\hline Farm size (78.29 ha) & 3,533 & 15,912 & 12,379 \\
\hline Wheat & 3,700 & 13,650 & 9,950 \\
\hline Maize & 2,260 & 4,920 & 2,660 \\
\hline Sunflower & \multicolumn{5}{|l|}{} \\
\hline Soybean &
\end{tabular}

Source: Calculation of the authors based on the results of the Survey

The greatest effect of increased costs of use of mineral fertilizers, as one of the measures to increase the intensity of production, also in case of family farms of the variant II, was recorded on the smallest family farms and ranged from a maximum of $26,300 \mathrm{RSD} / \mathrm{ha}$ in soybean production to minimum $13,850 \mathrm{RSD} /$ ha in wheat production, showing once again the absence of rational use of arable land on these farms as one of the most important resources of agricultural production. In case of the largest family farms, this effect was slightly smaller and ranged from just $2,660 \mathrm{RSD}$ /ha in soybean production to $12,379 \mathrm{RSD} /$ ha in maize production. The obtained results indicate that there were significant opportunities to increase the intensity of production of main field crops on family farms of both variants using large quantities of mineral fertilizers per hectare, i.e. by respecting received recommendations for a rational fertilization.

In order to evaluate the rationality of the utilization of the production potential of family farms and the economic effects of intensifying production of main field crops through application of the recommended quantities of mineral fertilizers, a larger number of indicators can be used. The gross margin is used as a main indicator of the productive capability, i.e. economic efficiency in the production of main field crops (Ivkov et al., 2008). In addition to gross margin, the following indicators are used: income per hectare and income per active member of the farm engaged exclusively in agriculture.

Fixed costs of surveyed family farms were estimated using data collected in the survey, as well as data obtained from the Tax Administration on the rate applied in the calculation of 
property taxes and water fees, as well as the rates for health insurance and pension (Munćan, 2011). The cost of insurance of field crops was estimated using average rates of the insurance company "Dunav", applied for the specific area where surveyed family farms operate, in the calculation of the insurance premiums. Depreciation and maintenance of commercial facilities were calculated at the rate of $2 \%$ of their appraised value, and the depreciation of the mechanization for service/exploitation life of 20 years.

The income of family farm shows how much the farm can spend over a certain period of time, without reducing its assets (Gogić, 2014). The income is calculated as the difference between the total value of production and external costs of materials, production services, depreciation, cost of insurance of products and equipment, the cost of land lease, interest on loans, property taxes and contributions. In this case, the income is the difference between total revenue and total cost of the farm.

By comparing the economic performance before and after the intensification, different effects on different groups of farms were observed. Namely, the most significant increase in gross margin per hectare of arable land by using the recommended quantities of mineral fertilizers was realized on the smallest family farms and the variant I by $53 \%$ and in case of farms of variant II this increase was $63 \%$, which is understandable in view of the previously presented findings that these farms apply the lowest level of intensity of production. Contrary to above said, significantly higher level of intensity that was achieved on 50-100 ha size farms, contributed to the realization of the highest gross margin per unit area before intensifying. The gross margin per unit of arable land increased by $13 \%$, post-intensification, on 50-100 ha farms of the variant I and by $11 \%$ on farms of variant II (Graph 1).

Graph 1. Gross margin per hectare of the surveyed farms before and after using the recommended quantities of mineral fertilizer

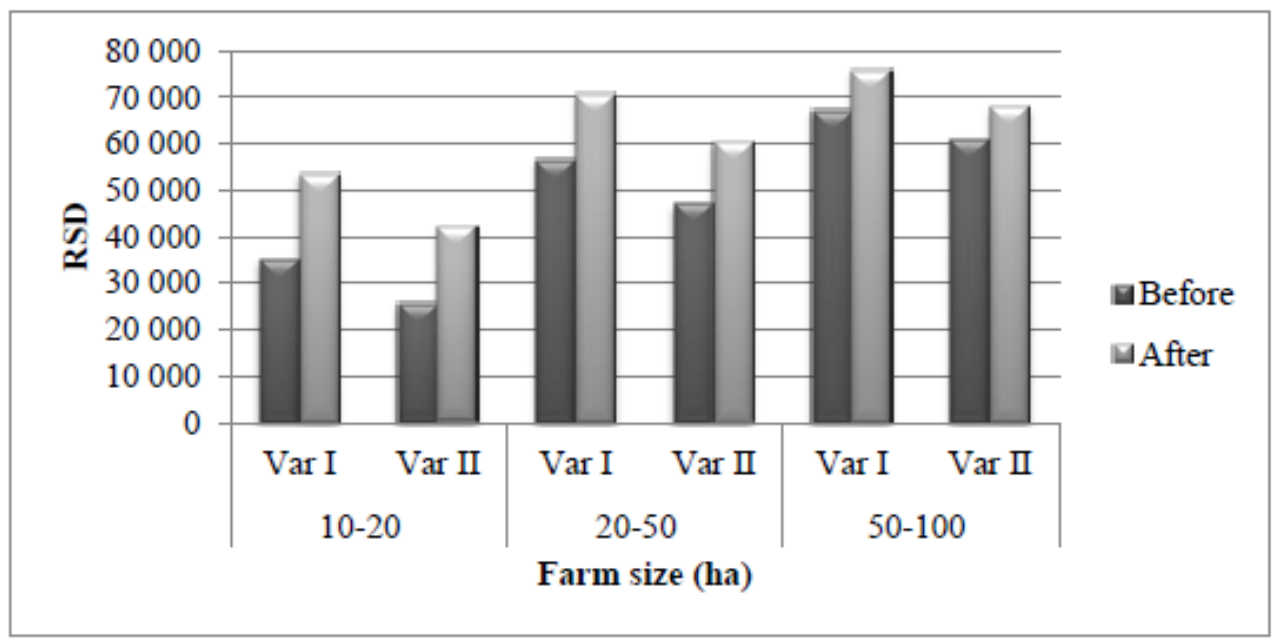

Source: Calculation of the authors

The effect of the recommended quantities of mineral fertilizers, expressed as the income per unit area and per active member of the farm engaged exclusively in agriculture, was 
manifested in an increase of $72 \%$ on the smallest family farms of the variant I. Farms of the variant II showed almost doubled increase of $98 \%$. On the largest family farms, the implementation of the recommended quantities of mineral fertilizers showed much more modest growth of these indicators, for family farms of the variant I - 19\% and family farms of the variant II - 18\% (Graphs 2 and 3).

Graph 2. Income per hectare of the surveyed farms before and after using the recommended quantities of mineral fertilizer

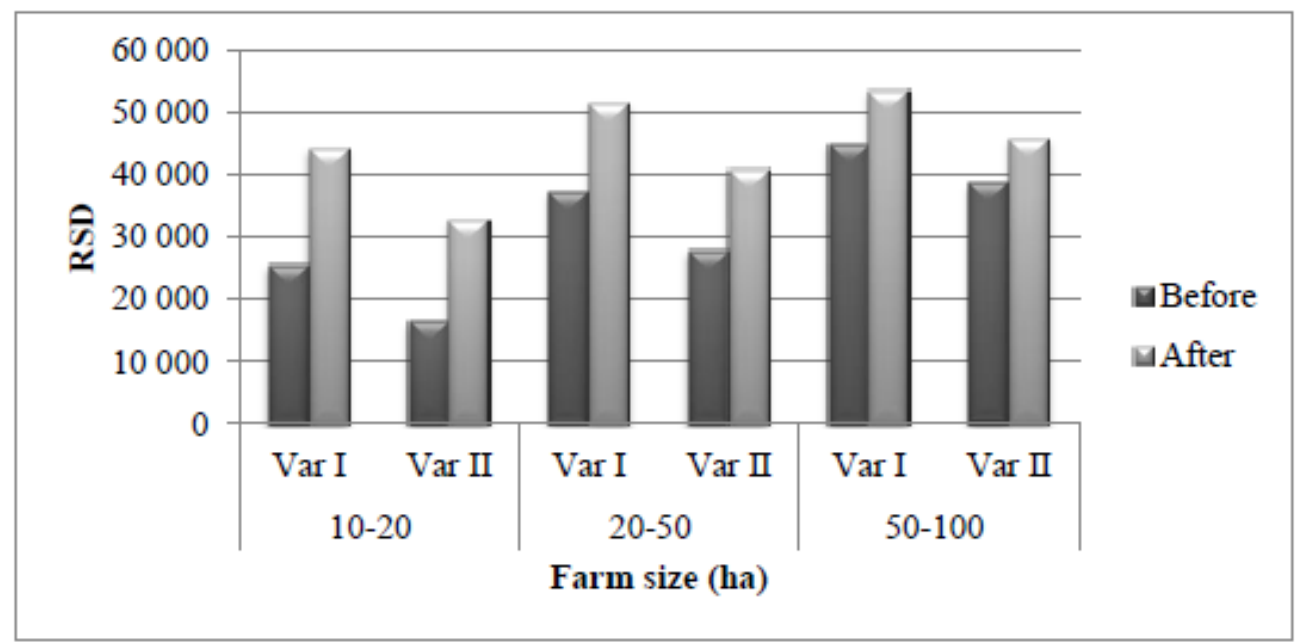

Source: Calculation of the authors

The calculated economic indicators of the intensification of the production of main field crops fully justify increased investment in the mineral fertilizer and confirm the initial assumption that the rational use of fertilizers through application of the recommended quantities based on the analysis of fertility parameters, is a very powerful tool for intensifying the production of main field crops on family farms. 
Graph 3. Income per active member of the surveyed farms before and after using the recommended quantities of mineral fertilizer

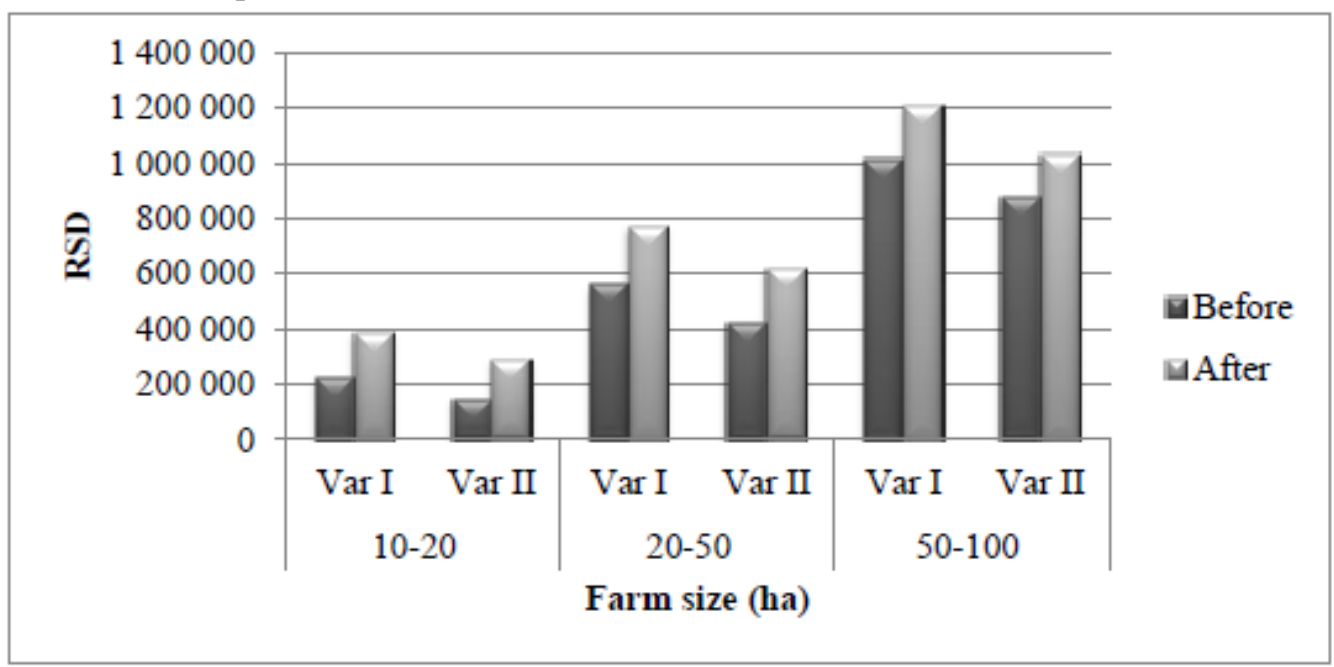

Source: Calculation of the authors

\section{Conclusion}

The research results confirm the initial assumption that the intensity of production of main field crops on family farms can be increased to a higher level by rational utilization of mineral fertilizers. The most significant effects of intensifying production, using the recommended quantities of mineral fertilizers, were realized on the smallest family farms.

By respecting received recommendations for rational fertilization with mineral fertilizers on the smallest family farms, variant I, the average yield of wheat would increase by $36.6 \%$, of maize by $15.9 \%$ and sunflower by $33.1 \%$. In case of farms of the variant II, the average yield of wheat would increase by $31.8 \%$, by $33.3 \%$ in maize production, by $39.1 \%$ in production of sunflower and by $39.2 \%$ in production of soybean.

Also, intensifying of production resulted in an increase in gross margin in case of the smallest farms by approx. $53 \%$ in the variant I, and by $63 \%$ in case of farms of the variant II.

The effect of intensifying production of main field crops, expressed as income per unit area and per active member of the farm engaged solely in agriculture, resulted in an increase of $72 \%$ to $98 \%$ on the smallest family farms.

\section{Literature}

1. Božić D., Munćan, P. (2015): Regional aspects of family holdings structure in the Republic of Serbia, Economics of agriculture, Vol. 62, No. 1, Institute of Agricultural Economics, Belgrade, pp. 107-123.

2. Bošnjak D., Rodić V. (2010): Komparativna analiza troškova proizvodnje osnovnih ratarskih useva u Vojvodini, Ekonomika poljoprivrede, Vol. 57, No. 2, Institut za 
ekonomiku poljoprivrede, Beograd, pp. 233-243.

3. D’Andrea, K.E., Otegui, M.E., Cirilo, A.G. (2008): Kernel number determination differs among maize hybrids inresponse to nitrogen, Field Crops Research, Vol. 105, pp. 228239.

4. Đukić, V., Balešević-Tubić, S., Đorđević, V., Tatić, M., Dozet, G., Jaćimović, G., Petrović, K. (2009): Uticaj đubrenja na prinos soje, Zbornik radova, Vol. 46, Naučni institut za ratarstvo i povrtarstvo, Novi Sad, pp. 17-23.

5. Glamočlija, Đ. (2006): Specijalno ratarstvo, Poljoprivredni fakultet, Beograd.

6. Gogić, P. (2014): Teorija troškova sa kalkulacijama u proizvodnji i preradi poljoprivrednih proizvoda, Poljoprivredni fakultet, Beograd.

7. Ivkov, I., Todorović, S., Munćan, M. (2008): Bruto marža kao značajan pokazatelj poslovanja poljoprivrednih gazdinstava, Tematski zbornik „Agroekonomska nauka i struka u tranziciji obrazovanja i agroprivrede“, Poljoprivredni fakultet, Beograd, pp. 235242.

8. Jaćimović, G., Marinković, B., Crnoborac, J. (2006): Prinos rafinisanog šećera $u$ zavisnosti od nivoa đubrenja šećerne repe, Savremena poljoprivreda, Vol. 54, No. 3-4, Novi Sad, pp. 285-289.

9. Jovanović, M., Bošnjak, D. (1997): Ekonomska efikasnost upotrebe mineralnih đubriva u ratarskoj proizvodnji, Zbornik radova „Troškovi, cene i pariteti u poljoprivredi Srbije“, Privredna komora Vojvodine, Novi Sad, pp. 145-163.

10. Kostov, P., Lingard, J. (2002): Subsistence farming in transitional economies: lessons from Bulgaria, Journal of Rural Studies, Vol. 18, No. 1, pp. 83-94.

11. Kresović M. (2010): Đubrenje ratarskih i povrtarskih kultura I deo Metode za određivanje potrebnih količina đubriva, Poljoprivredni fakultet, Beograd.

12. Ljubomirović, D., Filipović, V., Jovanović, B. (2006): Uticaj različitih količina NPK na osobine černozema u periodu 1970-2004. godina, Savremena poljoprivreda, Vol. 55, No. 5, Novi Sad, pp. 119-124.

13. Malešević, M., Crnoborac, J., Kastori, R. (2005): Primena azotnih đubriva i njihov uticaj na prinos i kvalitet proizvoda, Azot-Agrotehnički, fiziološki i ekološki aspekti, Novi Sad, pp. 233-267.

14. Maksimović L., Babović, J., Carić M., Milić, S. (2010): Ekonomski efekti navodnjavanja i đubrenja u proizvodnji šećerne repe, Ekonomika poljoprivrede, Vol. 57, No. 4, Institut za ekonomiku poljoprivrede, Beograd, pp. 611-623.

15. Munćan, P. (2011): Zavisnost dohotka porodičnih gazdinstava od veličine poseda $i$ strukture ratarske proizvodnje, Ekonomika poljoprivrede, Vol. 58, No. SB-2, Institut za ekonomiku poljoprivrede, Beograd, pp. 51-61.

16. Munćan, M. (2016): The impact of mineral fertilization and atmospheric precipitation on yield of field crops on family farms, Economics of Agriculture, Vol. 63, No. 3, Institute of Agricultural Economics, Belgrade, pp. 817-834. 
17. Munćan, P., Božić, D., Bogdanov, N. (2010): Ekonomska efikasnost proizvodnje ratarskih kultura na porodičnim gazdinstvima u AP Vojvodini, Ekonomika poljoprivrede, Vol. 57, No. 1, Institut za ekonomiku poljoprivrede, Beograd, pp. 15-24.

18. Munćan, P., Todorivić S., Munćan, M. (2014): Profitability of family farms directed at crop production, Economics of Agriculture, Vol. 61, No. 3, Institute of Agricultural Economics, Belgrade, pp. 575-585.

19.Sekulić, P., Vasin, J., Ninkov, J., Zeremski-Škorić, T., Milić, S., Kurjački, I., Šeremešić, S. (2009): Racionalizacija đubrenja mineralnim đubrivima u uslovima ekonomske krize, Ekonomika poljoprivrede, br. 2, Institut za ekonomiku poljoprivrede, Beograd, pp. 293-300.

20.Živković, B., Nejgebauer, V., Tanasijević, Đ., Miljković, N., Stojković, L., Drezgić, P (1972): Zemljišta Vojvodine, Institut za poljoprivrdna istraživanja, Novi Sad.

\title{
EKONOMSKI EFEKTI INTENZIVIRANJA PROIZVODNJE OSNOVNIH RATARSKIH USEVA ${ }^{7}$
}

\author{
Mihajlo Munćan ${ }^{8}$
}

\section{Rezime}

U ovom radu pošlo se od pretpostavke da se intenzivnost proizvodnje osnovnih ratarskih useva na porodičnim gazdinstvima može podići na viši nivo racionalnim utroškom mineralnih đubriva, kao jednom od najbržih, najjednostavnijih $i$ ekonomski najracionalnijih mera. Opredeljenje da se na ovaj način poveća nivo intenzivnosti proizvodnje osnovnih ratraskih useva proizašla je iz rezultata Ankete sprovedene na 75 porodičnih gazdinstava sa područja Vojvodine, koja je pokazala da porodična gazdinstva, i pored urađenih analiza zemljišta $i$ dobijenih preporuka od strane stručnih poljoprivrednih službi za optimalnu primenu mineralnih đubriva, u najvećem broju slučajeva (73\%) ne poštuju dobijene preporuke. Otuda je i cilj ovog rada procena ekonomskih efekata intenziviranja proizvodnje osnovnih ratarskih useva na porodičnim gazdinstvima racionalnijim korišćenjem mineralnih đubriva. Dobijeni rezultati pokazali su da se najznačajniji ekonomski efekti od intenziviranja proizvodnje mogu ostvariti na gazdinstvima veličine 10-20ha obradivog zemljišta.

Ključne reči: intenzivnost, mineralna đubriva, ratarski usevi, porodična gazdinstva, ekonomski efekti.

7 Rad je rezultat istraživanja na projektu „Ruralno tržište rada i ruralna ekonomija Srbije - diverzifikacija dohotka i smanjenje ruralnog siromaštva“, broj 179028, finansiranom od strane Ministarstva prosvete, nauke i tehnološkog razvoja Republike Srbije

8 Docent, dr Mihajlo Munćan, Univerzitet u Beogradu, Poljoprivredni fakultet, Nemanjina Ulica br. 6, 11080 Zemun, Republika Srbija, Telefon +381 11 4413416, E-mail: mmuncan@agrif.bg.ac.rs. 